\title{
Peningkatan Kualitas Batik Tulis Motif Tajung di Kelurahan Polagan Sampang Menggunakan Bahan Pewarna Alam Mangrove
}

\author{
Amirullah \\ Universitas Bhayangkara Surabaya
}

\author{
Tri Wardoyo \\ Universitas Bhayangkara Surabaya
}

\author{
Diana Rapitasari \\ Universitas Bhayangkara Surabaya
}

\begin{abstract}
Kampung Madegan and Kampung Tajung are one of coastal areas in Polagan Village of Sampang Regency. Along the coast there have long been growing mangrove trees and directly adjacent to the pond land. In the last ten years, mangrove vegetation in these two villages has decreased. The impact is when the sea is high tide, there is no natural retaining media so that water breaks through mangroves and directly enters to the pond. This sea water intrusion caused many unproductive population ponds to produce salt in dry season and milkfish or shrimp farming in rainy season. The decline in mangrove vegetation is caused by: (1) logging, branches and twigs of mangrove trees for firewood, (2) taking mangrove forest leaves as animal feed, (3) massive coastal sand mining especially when sea water recedes for building sand, (4) lack of knowledge and understanding of the community that the part of mangroves (branches and bark) types can be processed into natural dyes for making batik. KKN-PPM University of Bhayangkara Surabaya 2019 was held in Madegan and Tajung Villages. One of the program activities results is gentongan handmade batik Motif Tajung using dye material from the branches/bark of mangrove type Rhizophora Mucronata (Tinjang) by involving Tajung Laok Handmade Batik Manufacturers (Patner 1). The activity is expected to be able to increase community understanding, that mangroves aside from being a natural wave barrier, habitat for young fish and shrimp, and sources of oxygen, branches and bark can also be used as economically valuable products in the form of natural batik dyes, so that it is expected to encourage local communities to maintain its sustainability.
\end{abstract}

Keywords: Mangrove; Handmade Batik; Natural Dyes; Rhizophora Mucronata

\section{Abstrak}

Kampung Madegan dan Kampung Tajung merupakan salah satu wilayah pesisir di Kelurahan Polagan Kabupaten Sampang. Pada sepanjang pesisir pantai telah lama tumbuh pohon mangrove (bakau) dan berbatasan langsung dengan lahan tambak. Sekitar sepuluh tahun terakhir vegetasi mangrove di kedua kampung ini semakin berkurang. Dampaknya ketika laut pasang, tidak ada media penahan alami sehingga air menerobos mangrove dan langsung masuk ke lahan tambak. Intrusi air laut ini menyebabkan banyak tambak penduduk tidak produktif lagi baik menghasilkan garam di musim kemarau dan budidaya ikan bandeng atau udang di musim penghujan. Penurunan vegetasi mangrove dipicu oleh: (1) penebangan kayu, dahan, dan ranting pohon mangrove untuk kayu bakar, (2) pengambilan daun hutan mangrove sebagai pakan ternak, (3) penambangan pasir pantai secara masif khususnya ketika air laut surut untuk pasir bangunan, (4) minimnya pengetahuan dan pemahaman masyarakat bahwa bagian mangrove (dahan dan kulit batang) jenis dapat diolah menjadi bahan pewarna alam batik tulis.KKN-PPM Universitas Bhayangkara Surabaya 2019 dilaksanakan di Kampung Madegan dan Kampung Tajung.Salah satu hasil kegiatan program adalah batik tulis gentongan Motif Tajung menggunakan bahan pewarna dari dahan/kulit batang mangrove jenis Rhizophora Mucronata (tinjang) dengan melibatkan Kelompok Pengrajin Batik Tulis Tajung Laok (Mitra 1).Kegiatan diharapkan mampu meningkatkan pemahaman masyarakat, bahwa mangrove selain sebagai penahan ombak alami, habitat bagi ikan maupun udang muda, dan sumber oksigen, dahan dan kulit batangnya dapat juga dimanfaatkan menjadi produk bernilai ekonomis berupa bahan pewarna alam batik tulis, sehingga mampu meningkatkan kualitas batik tulis Motif Tajung sekaligus mendorong masyarakat lokal menjaga kelestarian Mangrove.

Kata kunci: Mangrove; Batik-Tulis; Pewarna-Alam; Rhizophora Mucronata

\section{Pendahuluan}

Kabupaten Sampang secara administratif terletak dalam wilayah Propinsi Jawa Timur yang secara geografis terletak diantara 113,08'-113,39' Bujur Timur dan 6,05'-7,13' Lintang Selatan. Kabupaten Sampang terletak kurang lebih 91.5 kilometer dari Surabaya dan dapat ditempuh dengan melalui Jembatan Surabaya-Madura (Suramadu) selama 1,5 jam atau dengan perjalanan laut 45 menit dilanjutkan perjalanan darat kurang lebih 2 jam. 


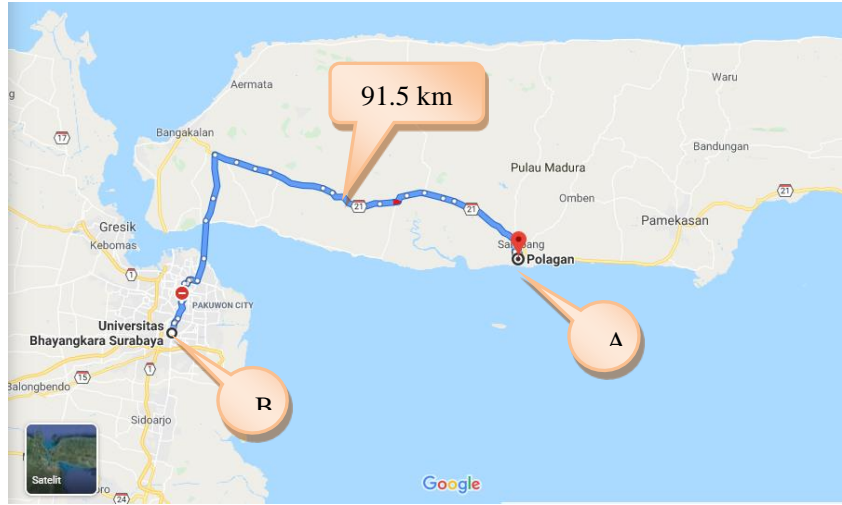

Gambar 1. Peta Lokasi Mitra di Kelurahan Polagan Sampang (A) dan Kampus Pelaksana KKN PPM (B) berjarak 91,5 km

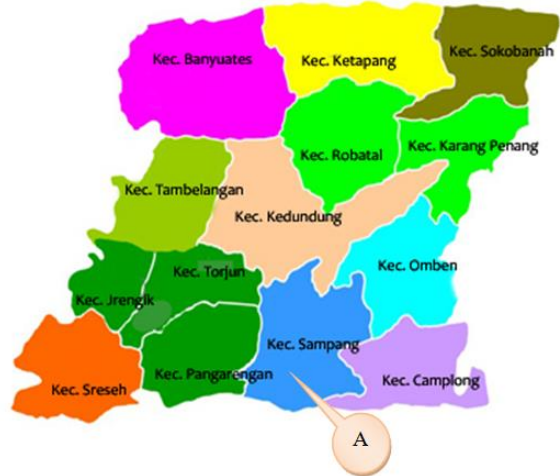

Gambar 2. Peta Kecamatan di Kabupaten Sampang(Kec. Sampang A)

(Amirulloh, 2019)

Kecamatan Sampang merupakan salah satu dari 14 kecamatan di Kabupaten Sampang. Kecamatan Sampang mempunyai 12 desa dan 6 kelurahan serta merupakan pusat kegiatan pemerintahan, ekonomi, barang dan jasa di Kabupaten Sampang .Kelurahan Polagan, Desa Aengsareh, Kelurahan Banyuanyar, dan Pulau Mandangin merupakan empat desa/kelurahan pesisir di Kecamatan Sampang.Kelurahan Polagan secara administratif berada di Kecamatan Sampang (Kecamatan Kota) Kabupaten Sampang. Kelurahan ini mempunyai lima dusun dan 18 RT. Lima Kampung (Dusun) di Kelurahan Polagan adalahKampung Tajung, Duko, Halelah, Madegan, dan Ponjuk (anonim, 2017a) Rata-rata masyarakat Kelurahan Polagan berprofesi sebagai pengrajin batik, pedagang, petani (sawah), petani garam, pengrajin mebel, pegawai negeri, dan sektor swasta.Kampung Tajung Kelurahan Polagan merupakan salah satu sentra pengrajin batik tulis di Kabupaten Sampang selain di Desa Kotah Kecamatan Jrengik.

Program KKN PPM menggandeng Kelompok Pengrajin Batik Tulis Tajung Laok (Bahasa Madura: Selatan) sebagai Mitra 1 dibawah pimpinan Siti Chotijah.Mitra pertama berlokasi di Kampung Tajung Kelurahan Polagan Kecamatan Sampang, Kabupaten Sampang.Kampung Madegan terletak di bagian barat Kelurahan Polagan, secara administratif juga termasuk dalam Kecamatan (Kota) Sampang Kabupaten Sampang.Penduduk Kampung Madegan umumnya berprofesi sebagai pedagang, petani (sawah), petani garam, nelayan pengrajin mebel, pegawai negeri, dan sektor swasta.Sekitar $80 \%$ wilayah Kelurahan Polagan terdiri dari lahan sawah dan tambak.Pada musim hujan, petani setempat memanfaatkan lahan tambak untuk membudidayakan ikan air payau (ikan bandeng dan udang), sedangkan pada musim kemarau mayoritas lahan dipakai untuk memproduksi garam. Kegiatan KKN-PPM juga akan menggandeng kelompok petani garam lokal Kampung Madegan dibawah pimpinan Abidarrin sebagai Mitra 2. Jumlah anggota kelompok petani garam lokal ini berjumlah 20 petani.Kegiatan KKN PPM dilaksanakan di dua Kampung (Dusun) yaitu Kampung Tajung dan Kampung Madegan.Gambar 3 dan 4 menunjukkan peta lokasi pelaksanaan KKN-PPM di Kelurahan Polagan.

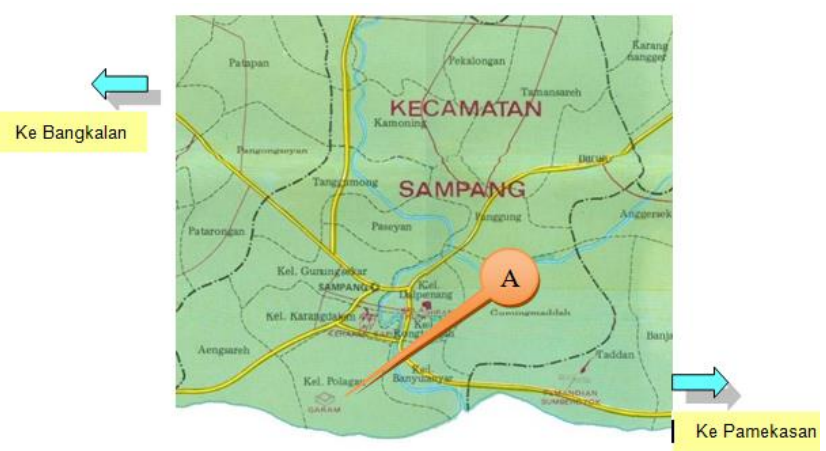

Gambar 3. Peta wilayah Kelurahan Polagan (A) terhadap Kecamatan Sampang

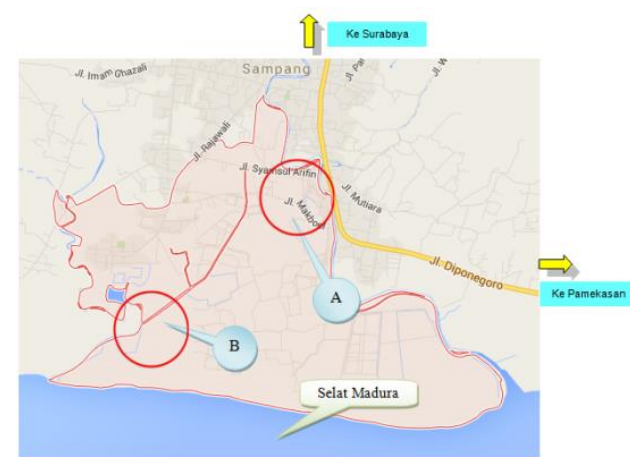

Gambar 4. Peta Kampung Tajung (A) dan Kampung Madegan (B) Kelurahan Polagan 
Ada dua kelompok wilayah Madura yang secara tradisional mempunyai kemahiran membatik tulis yang diwariskan turun temurun.Kelompok pertama adalah wilayah batik tulis di daerah pesisir pantai seperti Tanjungbumi Bangkalan.Kelompok kedua adalah wilayah pedalaman seperti Sampang, Pamekasan dan Sumenep.Batik Sampang merupakan salah satu batik khas Madura umumnyamenggunakan motif flora dan fauna di atas bahan sutera dan katun yang tidak kalah dengan batik daerah lain. Perpaduan gaya dan motif ini menghasilkan busana yang elegan, mewah, dan mahal.Motif batik Sampang biasanya menggunakan tema flora dan fauna dengan warna-warna terang dan mencolok (anonim, 2017b). Sentra batik tulis di Kabupaten Sampang dikembangkan di dua lokasi yaitu Kampung Tajung Kelurahan Polagan Kecamatan Kota Sampang dan Desa Kotah Kecamatan Jrengik.Batik Tulis Kotah mempunyai motif dan warna hampir sama dengan batik Madura umumnya. Motif kembang dan burung paling dominan dengan warna merah dan hijau.Batik itu digambar di atas kain katun yang dibeli dari Surabaya.Harga kain batik Kotah mulai dari Rp 150 ribu hingga Rp 1 juta per lembar tergantung dari kualitas katun.Hingga kini pembatik Madura belum berani bereksperimen seperti pembatik Pekalongan dengan membuat pakaian modis lengan pendek yang santai dan digemari masyarakat.Mereka masih menjual dalam bentuk bahan kain yang dipotong untuk kemeja, blus, atau sarung.Gambar 5 menunjukkan beberapa Motif Batik Kotah Sampang (Panggabean, 2013)
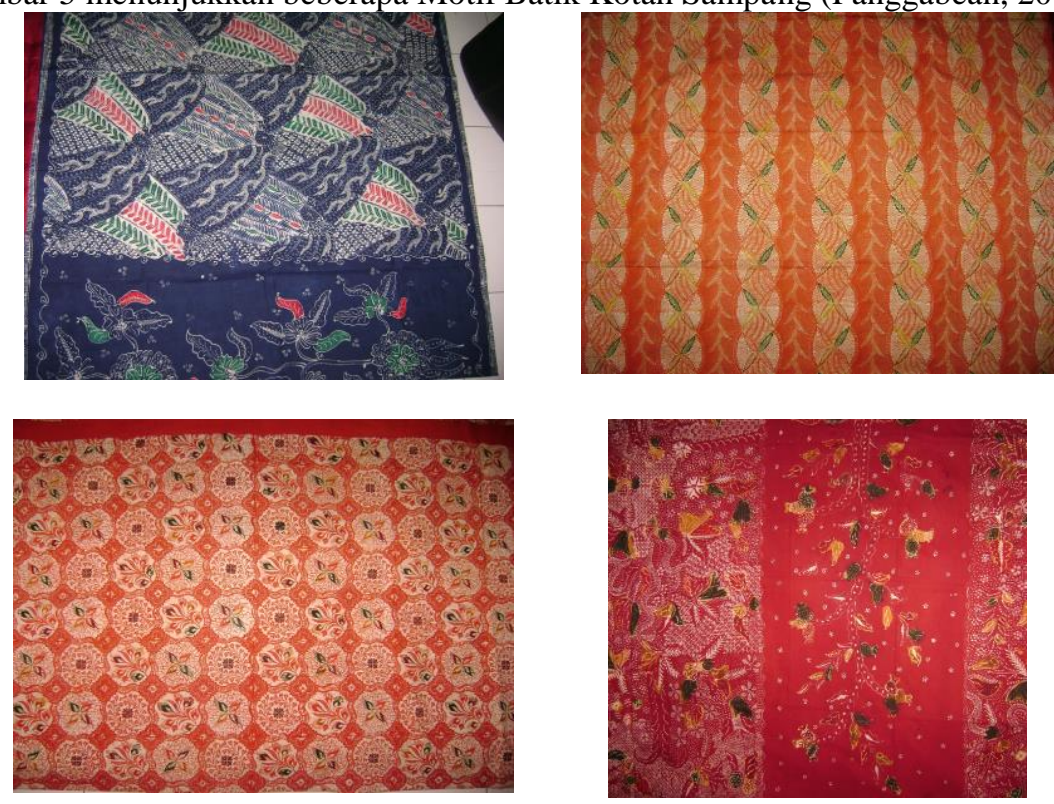

Gambar 5. Motif Flora dan Fauna pada Batik Tulis Kotah Sampang

Walaupun masuk pedalaman, secara geografis Kampung Tajung Kelurahan Polagan merupakan salah satu daerah pesisir di selatan Pulau Madura. Berdasarkan riwayat, dahulu, batik tulis menjadi pekerjaan perempuan untuk mengisi waktu luang sambil menunggu suami mereka yang bekerja sebagai nelayan mencari ikan di laut pesisir selatan Selat Madura. Bagi perempuan Kampung Tajung, menunggu kedatangan suami merupakan saat saat paling panjang dan membosankan.Mereka selalu gelisah apakah suaminya bisa pulang kembali dengan selamat dan bisa membawa ikantangkapan untuk menghidupi keluarga.Untuk mengurangi rasa gelisah tersebut, akhirnya mereka mulai belajar membatik, walaupun hingga kini belum ada yang dapat memastikan kapan para istri itu mulai membatik.Selain itu, batik juga digunakan sebagai simpanan yang diperlakukan sebagai emas atau tabungan.Batik tersebut juga disimpan untuk diserahkan kepada anak dan cucu, sebagai tanda kasih dan cinta ibu.Batik menjadi salah satu sumber kekayaan dan kebanggaan mereka sehingga tidak mengherankan jika mereka melakukan aktivitas tersebut dengan sepenuh hati.Dalam perkembangannya, nilai ini semakin bergeser karena zaman, membatik bukan lagi sebagai tanda kasih dan cinta ibu, namun semata-mata untuk mencari uang.Nilai komersial ini menjadi salah satu sebab mengapa hasil penggarapan batik tidak lagi sebagus dahulu.Kondisi letak geografis inilah yang menyebabkan Motif Batik Tajung sedikit berbeda dibandingkan Batik Kotah walaupun berasal dari kabupaten sama. Ciri khas yang menonjol pada Batik Tajung adalah adanya motif fauna berupa burung (manok) danikan laut (juko

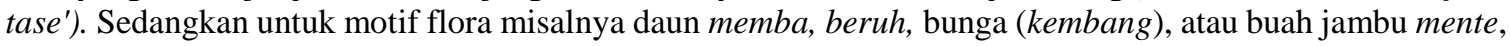
rata-rata hampir sama dengan Batik Tulis Kotah. Gambar 6 menunjukkan contoh motif Batik Tulis Tajung yang cukup populer (Alim, 2016). 

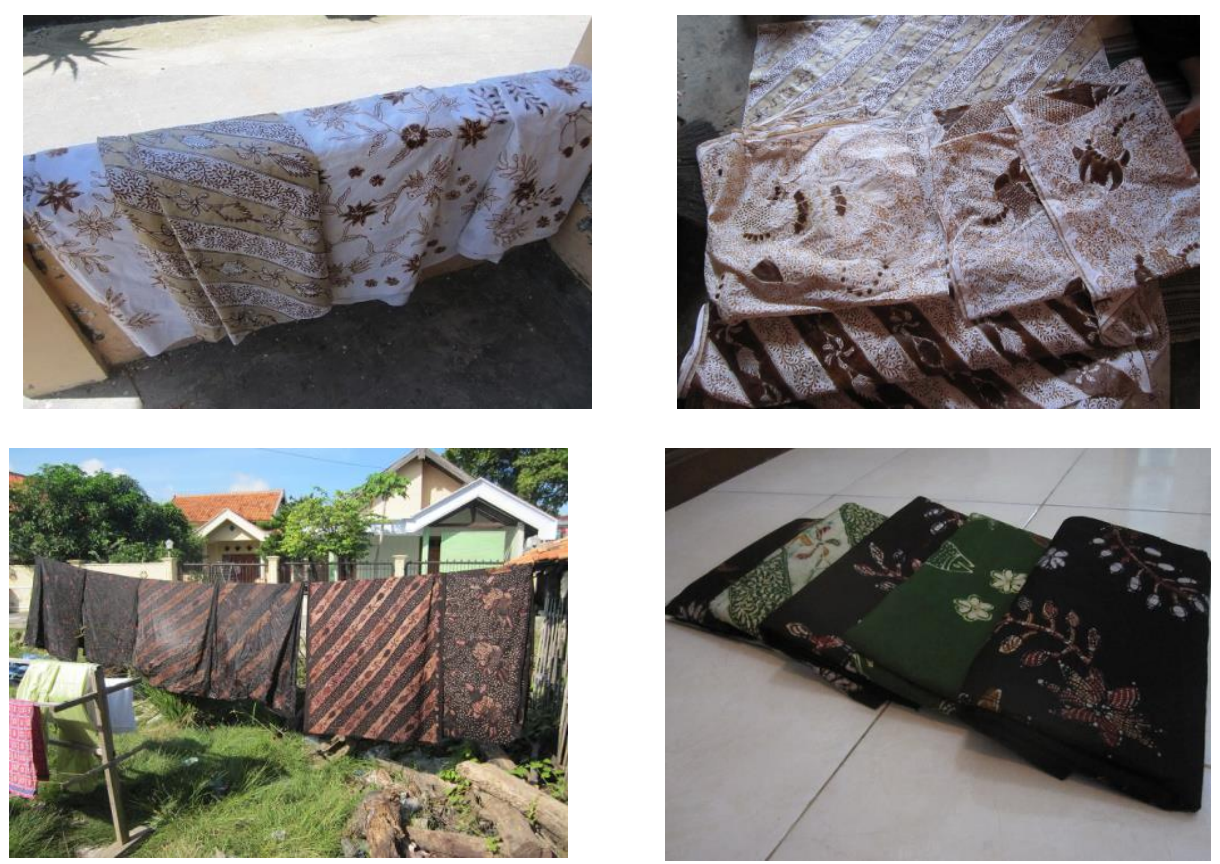

Gambar 6. Motif dan Hasil Kain Sudah Jadi pada Batik Tulis Motif Tajung Sampang

\section{Prioritas Permasalahan Mitra}

Permasalahan yang mengemuka adalah kerusakan akibat berkurangnya atau penggundulan vegetasi hutan mangrove alami oleh masyarakat setempat di pesisir pantai yang berbatasan dengan lahan tambak di Kampung Madegan Kelurahan Polagan.Mayoritas penduduk kampung tersebut mempunyai mata pencaharian sebagai petani tambak garam (musim kemarau) dan budidaya ikan air payau (musim hujan).Degradasi sumberdaya pesisir yang menonjol wilayah ini adalah degradasi hutan mangrove akibat konversi hutan mangrove menjadi kawasan pertambakan. Ada tiga jenis tanaman mangrove yang tumbuh di sepanjang pesisir Kelurahan Polagan yaitu Rhizophora Mucronata (mangrove atau tinjang), Avecennia Marina (api-api), dan Bruguiera Gymnorhiza (Bogem).Degradasi hutan mangrove pada pesisir pantai di Kampung Madegan juga terjadi akibat pemanfaatan intensif kayu untuk bahan bakar, bangunan, dan daunnya untuk makanan ternak, serta paling menonjol penambangan pasir laut di kawasan mangrove.

Akibat pemanfaatan kawasan konservasi yang tidak seimbang, maka hutan mangrove di Kampung Madegan mengalami perubahan cenderung menyebabkan penyusutan luasan. Rusaknya kawasan hutan mangrove pada pesisir pantai ini, menyebabkan penurunan fungsi hutan mangrove baik secara fisik untuk melindungi masuknya air laut ke lahan tambak garam serta ekologis dan ekonomis sebagai habitat biota laut seperti ikan, kepiting, dan udang bagi nelayan. Dampak kerusakan adalah abrasi di sepanjang pantai Kampung Madegan sehingga diperlukan tanggul terbuat dari tanah liat sebagai penahan ombak sepanjang kurang lebih $5 \mathrm{~km}$. Kerusakan hutan mangrove di pesisir Kampung Tajung selanjutnya juga dipicu oleh kegiatan penambangan pasir ilegal. Penambangan pasir sampai sekarang masih dilakukan baik secara diamdiam maupun terang-terangan masyarakat sekitar khususnya ketika air laut surut. Akibatnya penambangan, luas hutan mangrove semakin menyempit sehingga menyebabkan abrasi pada tanggul pembatas pantai dengan lahan tambak. Dampak kerusakan adalah jebolnya tanggul sehingga ketika air pasang ombak (rob) langsung menerobos masuk dan menyebabkan kerusakan areal lahan tambak. Kerusakan ini menyebabkan pemilik lahan (petani) tidak dapat memanfaatkan lahan secara ekonomi (dibiarkan terlantar), baik untuk menghasilkan garam lokal (musim kemarau) dan budidaya ikan air payau (musim hujan) misal bandeng, udang, atau kepiting. Akar persoalan diatas disebabkan oleh masyarakat lokal di Kampung Tajung dan Kampung Madegan mempunyai pengetahuan dan pemahaman yang minim bahwa ada bagian dari pohon bakau (daun dan buah) dapat diolah menjadi produk bernilai ekonomis tinggi (makanan dan minuman, bernilai ekonomis, serta bahan pewarna alam untuk batik tulis).Kegiatan KKN-PPM Tahun 2019 dilaksanakan di Kampung Madegan dan Kampung Tajung.Salah satu mata kegiatan KKN PPM adalah adalah sosialisasi, pelatihan, dan praktek pemanfaatan buah atau daun pohon bakau sebagai bahan warna bagi pembuatan batik tulis gentongan kepada Kelompok Pengrajin Batik Tulis Tajung Laok.Tujuan kegiatan 
adalah memberikan edukasi bagi masyarakat ikut serta mengelola hutan bakau untuk mencegah abrasi di sepanjang pesisir pantai Kampung Tajung dan Madegan Kelurahan Polagan. 


\section{PERMASALAHAN (PM)}

1. Penebangan kayu, dahan, dan ranting pohon bakau sebagai bahan untuk kayu bakar di pesisir pantai berbatasan dengan lahan tambak Kampung Madegan.

2. Pengambilan daun hutan bakau sebagai pakan ternak di pesisi pantai berbatasan dengan lahan tambak Kampung Madegan

MITRA

1. Kelompok Pengrajin Batik Tulis Tajung Laok.

2. Kelompok Petani Garam Lokal Kampung Madegan

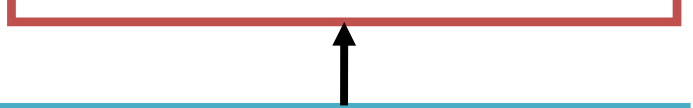

\section{TIM PELAKSANA}

1. Dr. Amirullah, ST, MT

2. (Ketua Tim)

3. Ir. Tri Wardoyo, MT. (Anggota Tim/DPL 1)

4. Diana Rapitasari, SE, MM (Anggota Tim/DPL 2)

\section{TENAGA AHLI}

1. Ali Mansyur, S.Ag. (Budidaya Bibit Bakau )

Soni Muchson.

(Produk Olahan Bakau)

3. Ali Murtono, S.Psi.

(Batik Pewarnaan Alam Bakau)

Gambar 7. Detail Permasalahan dan Program KKN-PPM di Kelurahan Polagan Kecamatan Sampang
3. Penambangan pasir pantai secara terus menerus khususnya ketika air laut surut sebagai bahan pasir untuk bangunan di pesisir pantai berbatasan dengan lahan tambak Kampung Madegan

4. Minimnya pengetahuan dan pemahaman masyarakat di Kampung Tajung dan Kampung Madegan bahwa bagian dari pohon bakau (daun dan buah) dapat diolah menjadi produk bernilai ekonomis tinggi (makanan dan minuman,

\section{DAMPAK}

1. Kerusakan vegetasi hutan bakau alami di pesisir pantai yang berbatasan dengan lahan tambak di Kampung Madegan.

2. Abrasi pada beberapa titik di pesisir pantai berbatasan dengan lahan tambak di Kampung Madegan.

3. Abrasi pada tanggul pembatas pantai dengan lahan tambak sehingga menyebabkan tanggul roboh (jebol) berdampak air pasang ombak (rob) dari laut langsung menerobos masuk dan menyebabkan kerusakan areal lahan tambak di Kampung Madegan.

4. Pemilik lahan dan petani tidak bisa lagi memanfaatkan lahan tambak secara ekonomi baik untuk menghasilkan garam lokal (musim kemarau) dan budidaya ikan air payau (musim hujan) misal bandeng, udang, atau kepiting. Lahan tambak yang rusak dibiarkan dalam kondisi terlantar karena untuk melakukan rehabilitasi tambak dibutuhkan biaya sangat besar. bernilai ekonomis, serta bahan pewarna alam batik tulis).

\section{SOLUSI YANG DITAWARKAN}

1. Peningkatan partisipasi masyarakat untuk ikut mengelola, mempertahankan kelestarian, rehabilitasi, dan memperluas areal hutan bakau melalui sosialisasi, pelatihan, praktek, budidaya dan pembibitan 100 bakau oleh masyarakat pesisir pantai yang berbatasan langsung dengan lahan tambak garam di Kampung Madegan (PM1, PM2, dan PM3)

2. Penghasilan tambahan secara ekonomis bagi masyarakat pesisir di Kampung Madegan melalui sosialisasi, pelatihan, dan praktek cara pengolahan buah bakau menjadi produk bernilai ekonomis berupa makanan dan minuman yaitu sirup bakau (Sonneratia Casiolaris), kerupuk bakau(Acanthus Illicipolius tua), dan teh bakau bakau(Acanthus Illicipolius muda) (PM 4).

3. Edukasi bagi masyarakat ikut serta mengelola hutan bakau untuk mencegah abrasi di sepanjang pesisir pantai Kampung Tajung dan Madegan Kelurahan Polagan melalui sosialisasi, pelatihan, dan praktek pemanfaatan buah atau daun pohon bakau sebagai bahan warna bagi pembuatan batik tulis gentongan "pewarnaan alam" kepada Kelompok Pengrajin Batik Tulis Tajung Laok (PM4).

\section{SASARAN KEGIATAN}

1. Kelompok Pengrajin Batik Tulis Tajung Laok (Mitra 1)

2. Kelompok Petani Garam Lokal Kampung Madegan (Mitra 2) 
Gambar 7. Detail Permasalahan dan Program KKN

PPM di Kelurahan Polagan Kecamatan Sampang
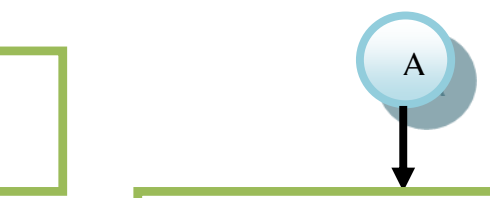

METODE PELAKSANAAN

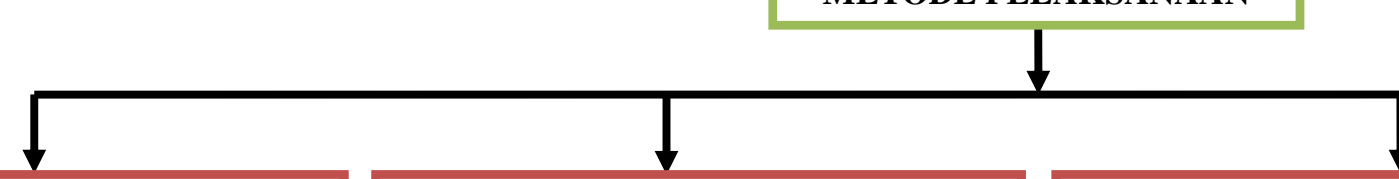

Pelatihan, sosialisasi, ceramah, diskusi, tanya-jawab, dan praktek dengan materi pengelolaan, mempertahankan kelestarian, rehabilitasi, dan memperluas areal hutan bakau sertabudidaya pembibitan 100 bakau oleh masyarakat pesisir pantai berbatasan langsung dengan lahan tambak garam di Kampung Madegan Kelurahan Polagan. Kegiatan melibatkan Kelompok Petani Garam Lokal Kampung Madegan (Mitra 2).
Pelatihan, sosialisasi, ceramah, diskusi, tanyajawab, dan praktek dengan materi memberikan penghasilan tambahan secara ekonomis bagi masyarakat pesisir di Kampung

Madeganmelalui pengolahan buah bakau menjadi produk bernilai ekonomis berupa makanan dan minuman bernilai ekonomis yaitu: sirup bakau (Sonneratia Casiolaris), kerupuk bakau(Acanthus Illicipolius tua), dan teh bakau(Acanthus Illicipolius muda) kepada Kelompok Petani Garam Lokal Kampung Madegan (Mitra 2).
Pelatihan, sosialisasi, ceramah, diskusi, tanya jawab dan praktek dengan materi pemanfaatan buah atau daun pohon bakau sebagai bahan warna bagi pembuatan batik tulis gentongan "pewarnaan alam" kepada Kelompok Pengrajin Batik Tulis Tajung Laok. Kegiatan merupakan edukasi bagi masyarakat ikut serta mengelola hutan bakau untuk mencegah abrasi di sepanjang pesisir pantai Kampung Tajung dan Madegan Kelurahan Polagan melibatkan Kelompok Pengrajin Batik Tulis Tajung Laok (Mitra 1).

\section{LUARAN}

1. Budidaya dan pembibitan 100 bakau oleh masyarakat pesisir pantai yang berbatasan langsung dengan lahan tambak garam di Kampung Madegan.

2. Produk makanan dan minuman berbahan buah bakau yaitu sirup bakau (Sonneratia Casiolaris), kerupuk bakau(Acanthus Illicipolius tua), dan teh bakau(Acanthus Illicipolius muda).

3. Produk Kain batik tulis Gentongan "Pewarnaan-Alam" Motif Tajung yang dibuat dengan memanfaatkan buah atau daun pohon bakau sebagai bahan pewarna alam bagi kain batik tulis.

4. Jurnal JPP Iptek (Pengabdian dan Penerapan Iptek) ITATS.

5. Proseding ilmiah seminar nasional.

6. Artikel di media massa cetak/online di www.ubhara.ac.id.

7. Video hasil kegiatan KKN PPM diunggah di Youtube.

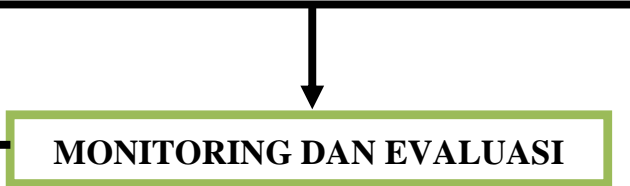

\section{MONITORING DAN EVALUAS}

\section{RENCANA KEBERLANJUTAN PROGRAM}

1. Pembentukan lembaga pemberdayaan ekonomi masyarakat pesisir di Kelurahan Polagan Kecamatan Sampang supaya hasil kegiatan KKN PPM dapat terus dilanjutkan oleh masyarakat lokal dibina oleh LPPM UBHARA Surabaya.

2. Pembentukan lembaga sosial kepemudaan yang peduli terhadap lingkungan dan kelestarian hutan bakau di Kelurahan Polagan.

3. Konsolidasi keberlanjutan Program KKN PPM dengan program Pemkab Sampang supaya memasukkan program penanaman bibit pohon bakau, pemanfaataan buah pohon bakau menjadi bahan makanan, minuman, dan bahan pewarna alam kain batik tulis "Motif Tajung" menjadi program prioritas didukung oleh APBD.

4. Mewujudkan wilayah pesisir di Kelurahan Polagan sebagai Desa Ekowisata Bakau (Mangrove Centre) di Kecamatan Sampang. 
Gambar 7 menunjukkan bagan alir detail permasalahan dan programKKN-PPMdi Kelurahan Polagan Kecamatan Sampang. Bagian yang dicetak tebal menunjukkan salah satu mata kegiatan KKN PPM tentangpembuatan batik tulis gentongan "pewarnaan alam" kepada Kelompok Pengrajin Batik Tulis Tajung Laok dan secara khusus akan menjadi fokus pembahasan pada makalah ini.

\section{Metode Pelaksanaan}

\section{Metode Kegiatan}

Program KKN PPM dilaksanakan untuk memberdayakan Kelompok Pengrajin Batik Tulis Tajung Laok (Mitra 1) dan Kelompok Petani Garam Lokal Kampung Madegan (Mitra 2) untuk meningkatkan kualitas produksi, peningkatan pendapatan dan partisipasi, peningkatan swadana dan swadaya masyarakat, budidaya, pembibitan, serta rehabilitasi dan perlindungan varietas tanaman mangrove di wilayah pesisir Kelurahan Polagan Kecamatan Sampang Kabupaten Sampang Jawa-Timur. Salah satu kegiatan KKN-PPM adalah pelatihan, sosialisasi, ceramah, diskusi, tanya jawab dan praktek dengan materi pemanfaatan buah atau daun pohon bakau sebagai bahan warna bagi pembuatan batik tulis gentongan "pewarnaan alam" kepada Kelompok Pengrajin Batik Tulis Tajung Laok.Kegiatan merupakan edukasi bagi masyarakat ikut serta mengelola hutan bakau untuk mencegah abrasi di sepanjang pesisir pantai Kampung Tajung dan Madegan Kelurahan Polagan melibatkan Kelompok Pengrajin Batik Tulis Tajung Laok. Metode kegiatan diselenggarakan pertama melalui kunjungan ke UMKM Batik "Zulpah" di Kecamatan Tanjung Bumi. Tujuan kegiatan adalah melakukan pelatihan proses pewarnaan alam batik tulis Motif Tanjung Bumi menggunakan bahan Mangrove (daun dan kulit pohon). Hasil pelatihan selanjutnya akan menjadi materi bagi mahasiswa untuk melakukan pelatihan yang batik tulis pewarnaan alam dari bahan pohon Mangrove kepada Kelompok Batik Tulis Tajung Laok. Kegiatan kedua adalah adalah pelatihan, sosialisasi, dan praktek dengan materi pemanfaatan daun dan batang pohon bakau sebagai bahan pewarna bagi pembuatan batik tulis gentongan "pewarnaan alam” kepada Mitra 1.

\section{Partisipasi Mitra}

Untuk mendukung pelaksanaan program KKN-PPM tentu dibutuhkan partisipasi mitra.Mitra memfasilitasi dan menyediakan tempat bagi pelaksanaan kegiatan sosialisasi, pelatihan, praktek ceramah, diskusi, dan tanya-jawab membahas materi kegiatan.Mitra melakukan sosialisasi dan mobilisasi kepada anggota kedua mitra supaya mereka mengikuti semua sosialisasi, pelatihan, praktek, ceramah, diskusi, tanyajawab, dan kegiatan lapangan. Mitra memfasilitasi pembentukan panitia pelaksana terdiri dari tim pelaksana dan mitra serta bertugas memberikan pengarahan dan informasi kepada anggota Mitra 1 dan Mitra 2. Mitra memfasilitasi dan memberikan masukan kepada narasumber untuk menyukseskan kegiatan sesuai dengan target luaran.Mitra membantu menyiapkan kebutuhan pendukung kegiatan sosialisasi, pelatihan, praktek, ceramah, diskusi dan tanya-jawab meliputi; spanduk; makalah dan materi pelatihan, penyediaan koneksi listrik dan internet, meja-kursi, dan layar (screen) LCD proyektor.Mitra mengkoordinasikan kegiatan KKN PPM dengan anggota mitra mengenai jadwal yang sudah ditentukan oleh panitia pelaksana.

\section{Hasil dan Pembahasan}

\section{Kegiatan KKN PPM}

Program KKN PPM dilaksanakan untuk mencapai mencapai hasil yang diharapkan sesuai dengan tema yang diusulkan. Kegiatan pertama adalah survey dan observasi lapangan mengenai kondisi geografis kampung/desa/kecamatan sasaran, kondisi sosial budaya masyarakat setempat, mata-pencarian utama penduduk, jumlah kelompok sasaran. Survey lapangan juga dilakukan untuk mengetahui dan memetakan lokasi pesisir pantai yang mengalami abrasi terparah pada pesisir pantai berbatasan dengan lahan tambak garam ke Kampung Madegan Kelurahan Polagan. Kegiatan kedua adalah pembekalan kepada mahasiswa peserta KKN PPM oleh ketua pelaksana dan dosen pembimbing lapangan.. Metode kegiatan diselenggarakan pertama melalui kunjungan ke UMKM Batik “Zulpah" di Kecamatan Tanjung Bumi. Tujuan kegiatan adalah melakukan pelatihan proses pewarnaan alam batik tulis Motif Tanjung Bumi menggunakan bahan Mangrove (daun dan kulit pohon). Hasil pelatihan selanjutnya akan menjadi materi bagi mahasiswa untuk melakukan pelatihan yang batik tulis pewarnaan alam dari bahan pohon Mangrove kepada Kelompok Batik Tulis Tajung Laok (Mitra 1). Kegiatan kedua adalah adalah pelatihan, sosialisasi, dan praktek dengan materi pemanfaatan daun dan batang pohon bakau sebagai bahan pewarna bagi pembuatan batik tulis gentongan "pewarnaan alam" kepada Mitra 1. Tujuan kegiatan adalah memberikan edukasi bagi masyarakat ikut serta mengelola hutan bakau untuk mencegah abrasi di sepanjang pesisir pantai Kampung Tajung melalui pemanfaatan bagian pohon mangrove (kulit dan dahan) sebagai bahan batik pewarna alam oleh Mitra 1. 


\section{Survei Kegiatan}

Survei dan observasi lapangan dilakukan untuk mengetahui kondisi geografis kampung/desa/kecamatan sasaran, kondisi sosial budaya masyarakat setempat, mata-pencarian utama penduduk, jumlah kelompok sasaran. Tahapan ini dilakukan untuk mengetahui dan memetakan lokasi pesisir pantai yang mengalami abrasi terparah pada pesisir pantai berbatasan dengan lahan tambak garam ke Kampung Madegan Kelurahan Polagan. Untuk administrasi kegiatan lapangan pelaksana melakukan perijinan kegiatan ke Bakesbangpol Kabupaten Sampang dan Lurah Polagan.Kegiatan dilaksanakan oleh ketua pelaksana dan Mitra 2 dengan naik perahu menyusuri sungai, muara, dan pesisir pantai di Kampung Madegan.Kegiatan survei dan perijinan perijinan dilaksanakan adalah Kamis, 16 Mei 2019.

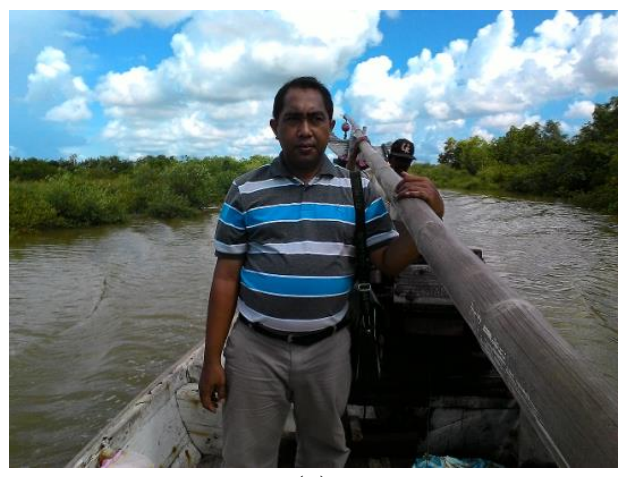

(a)

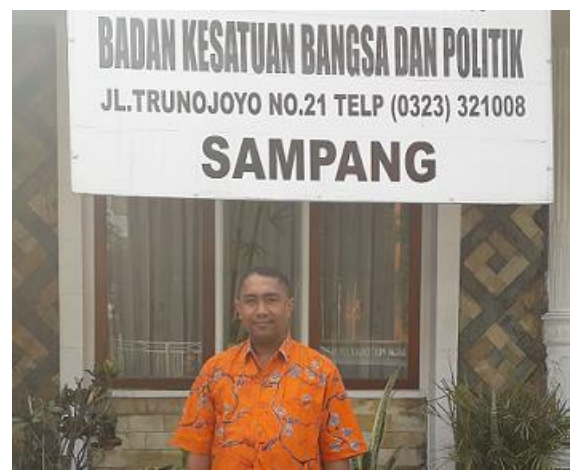

(b)

Gambar 8. (a) Survei lapangan dan (b) mengurus administrasi perijinan ke Bakesbangpol Sampang

\section{Pembekalan kepada Mahasiswa}

Pembekalan kepada mahasiswa dilakukan untuk melalakukan sosialisasi rencana kerja kegiatan KKN PPM. Topik kegiatan pembekalan kepada mahasiswa antara lain (a) pemahaman materi mengelola, mempertahankan kelestarian, rehabilitasi, dan memperluas areal hutan mangrove melalui sosialisasi, pelatihan, praktek, budidaya, di sepanjang pesisir pantai yang berbatasan langsung dengan lahan tambak garam serta pembibitan dan budidaya 100 pohon mangrove di Kampung Madegan Kelurahan Polagan, (b) pemanfaatan dan pengolahan buah mangrove menjadi produk bernilai ekonomis berupa makanan dan minuman yaitu sirup, kerupuk, dan teh berbahan mangrove, (c) Edukasi bagi masyarakat supaya membantu atau mengurangi angka pencurian kayu hutan mangrove untuk kayu bakar dan daun untuk makanan ternak, mengurangi kegiatan penambangan pasir pantai oleh masyarakat, dan mencegah abrasi di sepanjang pesisir pantai Kampung Tajung dan Kampung Madegan Kelurahan Polagan. Edukasi ditempuh dengan cara memanfaatkan buah atau daun pohon mangrove sebagai bahan pewarna alam batik tulis gentongan "Pewarnaan Alam" Motif Tajung. Kegiatan dilaksanakan oleh ketua dan dosen pembimbing lapangan (DPL).Kegiatan dilaksanakan di ruang dosen Prodi Teknik Elektro Fakultas Teknik pada hari Sabtu, 11 Mei 2019.
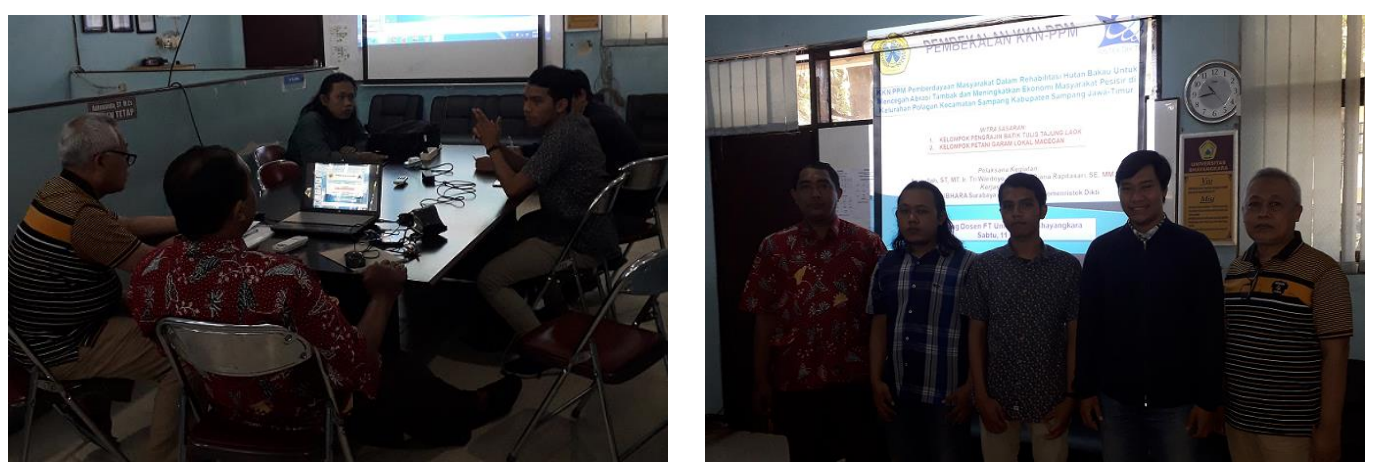

Gambar 9. Pembekalan kepada mahasiswa peserta KKN PPM 


\section{Kunjungan ke UMKM Batik "Zulpah" di Kecamatan Tanjung Bumi}

Kegiatan lapangan KKN PPM adalah pelaksana (Amirullah, ST, MT), DPL (Ir. Tri Wardoyo, MT), dan 2 mahasiswa (Nur Huda Dwi Ari Djatmiko dan Setyo Wahyu Windiarto) melakukan kunjungan ke UMKM Batik “Zulpah" di Dusun Kramat Desa Peseseh Kecamatan Tanjung Bumi Bangkalan pada Sabtu, 18 Mei 2019. Tujuan kegiatan adalah melakukan pelatihan proses pewarnaan alam batik tulis Motif Tanjung Bumi menggunakan bahan Mangrove (daun dan kulit pohon). Hasil pelatihan selanjutnya akan menjadi materi bagi mahasiswa untuk melakukan pelatihan yang batik tulis pewarnaan alam dari bahan pohon Mangrove kepada Kelompok Batik Tulis Tajung Laok. Gambar 11 menujukkan proses pembuatan Batik Tulis Gentongan menggunakan pewarnaan alam.

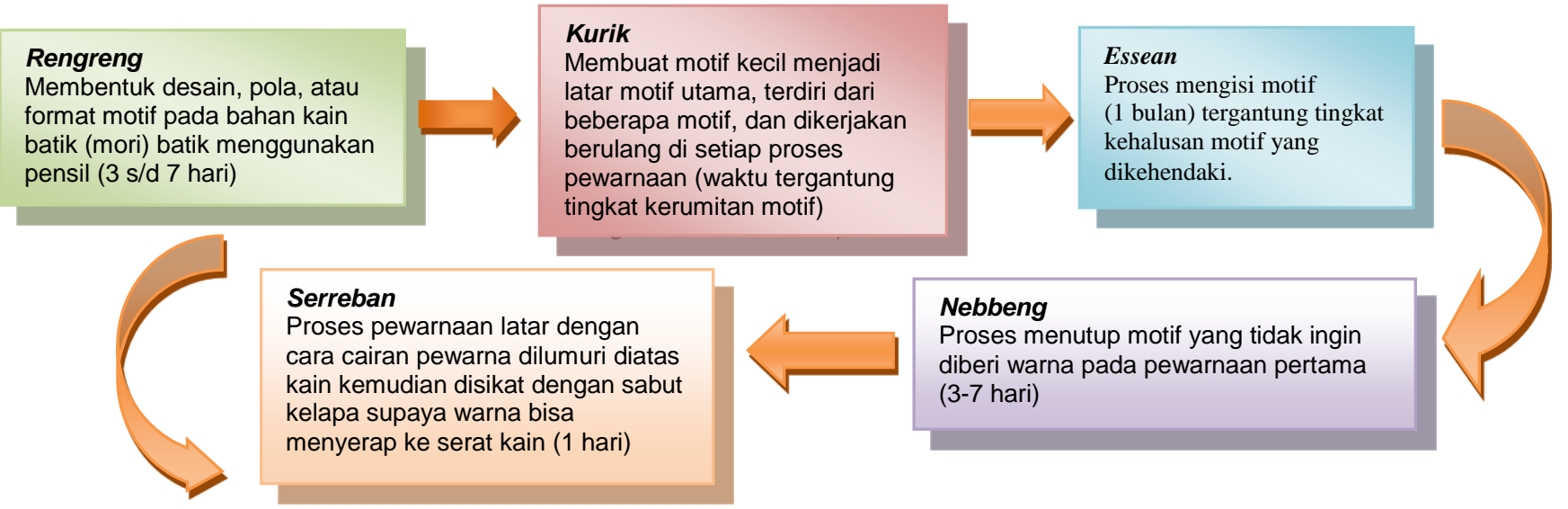

\begin{abstract}
Lorodan
Proses memisahkan malam (lilin) kain batik dengan cara menggodok pada air mendidih dicampur kanji di dalam tong besar ( $1 \mathrm{~s} / \mathrm{d} 2 \mathrm{jam})$.
\end{abstract}

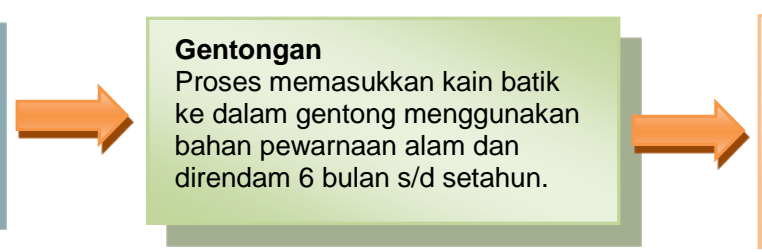

\section{Pengeringan}

Proses pengeringan kain batik dengan cara dijemur di bawah sinar matahari atau cukup di-angin-anginkan di bawah pohon saja (1 hari).

Gambar 10. Proses pembuatan Batik Tulis Gentongan menggunakan pewarnaan alam

Dusun Kramat Desa Peseseh merupakan salah satu sentra pembuatan dan usaha batik tulis di Kecamatan Tanjung Bumi Bangkalan. Kecamatan ini terletak kurang lebih 80 kilometer dari Surabaya dan dapat ditempuh melalui Jembatan Suramadu dengan waktu sekitar 1,5 jam dengan rute berturut-turut mulai dari pertigaan Desa Tengkel (Kecamatan Burneh), Kota Bangkalan, Kecamatan Arosbaya, Kecamatan Klampis, Kecamatan Sepulu, dan Kecamatan Tanjung Bumi. Alternatif menuju Kecamatan Tanjung Bumi juga bisa ditempuh melalui perjalanan laut menggunakan penyeberangan (kapal feri) dari Pelabuhan Ujung Surabaya menuju Kamal selama kurang lebih 45 menit dan dilanjutkan dengan perjalanan darat sekitar 2 jam.Pemilik UMKM batik tulis yang beralamat di Jalan Pelabuhan II Nomor 10 (Utara Polsek) Dusun Kramat Desa Peseseh Kecamatan Tanjung Bumi adalah Wurrotul Muhajjalah atau biasa dipanggil Ibu Wuri dibantu Suaminya Ali Mortono, S.Psi.Perempuan berjilbab ini membuka usaha batik tulis "Zulpah" sebagai bagian konsistensi untuk mewujudkan kecintaannya terhadap seni budaya warisan leluhur Madura dan melanjutkan usaha kerajinan yang telah dirintis serta sudah dikembangkan secara turun temurun oleh kedua orang-tuanya (Bapak dan Ibu Zulpah). Usaha kerajinan batik tulis secara konsisten menggunakan teknik pembuatan dan motif Batik Gentongan Tanjung Bumi dengan ciri khas warna lugas, tegas, menyolok, berani (colourful), dan memiliki aroma rempah-rempah karena perendaman. Motif tersebut antara-lain motif kembang randu, burung hong, sik melaya, ola'-ola' dan sejumlah motif lainnya. Produk batik tulis dari UMKM Batik Tulis "Zulpah" antara-lain kain batik tulis tunggal (per-potong), batik sarimbit (untuk pasangan suami-istri), taplak meja, samper atau kain batik panjang (Bahasa Jawa: sewek), dan batik tulis selendang lebar/panjang (pasmina) (Amirulloh, 2019) Saat ini UMKM Batik Tulis “Zulpah" Tanjung Bumi sedang mengembangkan batik tulis menggunakan pewarnaan alam dari daun dan batang/dahan pohon mangrove jenis Rhizophora Mucronata (mangrove atau tinjang). 

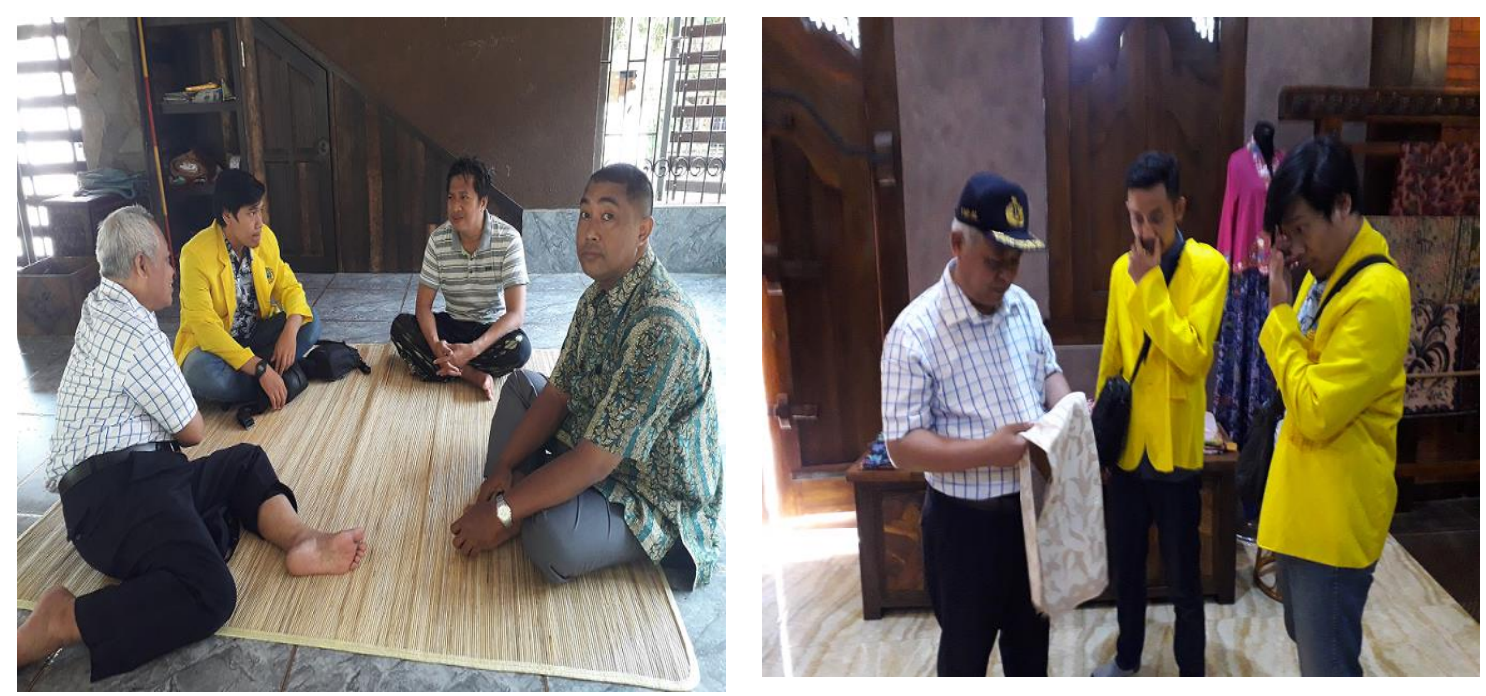

Gambar 11.(a) Diskusi dengan Ali Mortono, S.Psi sebagi Pemilik UMKM Batik “Zulpah” dan (b) Kain batik pewarnaan alam dari dahan mangrove jenis Rhizophora Mucronata
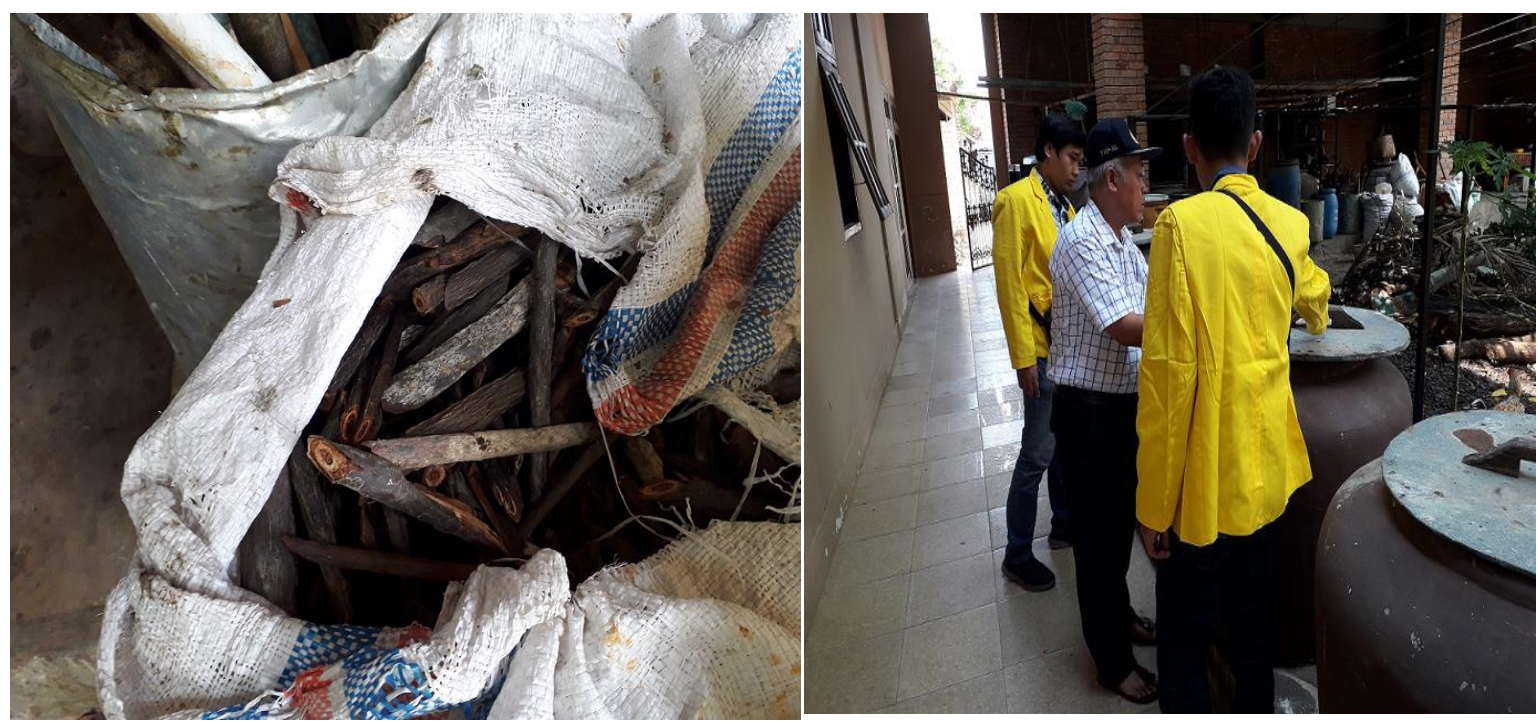

Gambar 12.Dahan mangrove jenis Rhizophora Mucronata dalam gentong untuk bahan pewarna alam

\section{Pelatihan Pewarnaan Alam Mangrove untuk Batik Tulis Motif Tajung}

Kegiatan KKN selanjutnya PPM adalah pelatihan, sosialisasi, dan praktek dengan materi pemanfaatan daun dan batang pohon bakau sebagai bahan warna bagi pembuatan batik tulis gentongan "pewarnaan alam" kepada Kelompok Pengrajin Batik Tulis Tajung Laok (Mitra 1). Kegiatan dilaksanakan pada Sabtu, 24 Agustus 2019 dihadiri oleh pelaksana (Amirullah, ST, MT), lima mahasiswa peserta KKN PPM dan pimpinan Mitra 1 (Siti Chotijah) di Kampung Tajung Kelurahan Polagan Kabupaten Sampang. Tujuan kegiatan adalah memberikan edukasi bagi masyarakat supaya ikut serta mengelola hutan bakau untuk mencegah abrasi di sepanjang pesisir pantai Kampung Tajung dan Madegan Kelurahan Polagan, dengan melibatkan Kelompok Pengrajin Batik Tulis Tajung Laok (Mitra 1)melalui pemanfaatan bagian pohon mangrove (kulit dan dahan) sebagai bahan batik pewarna alam oleh Mitra 1. 

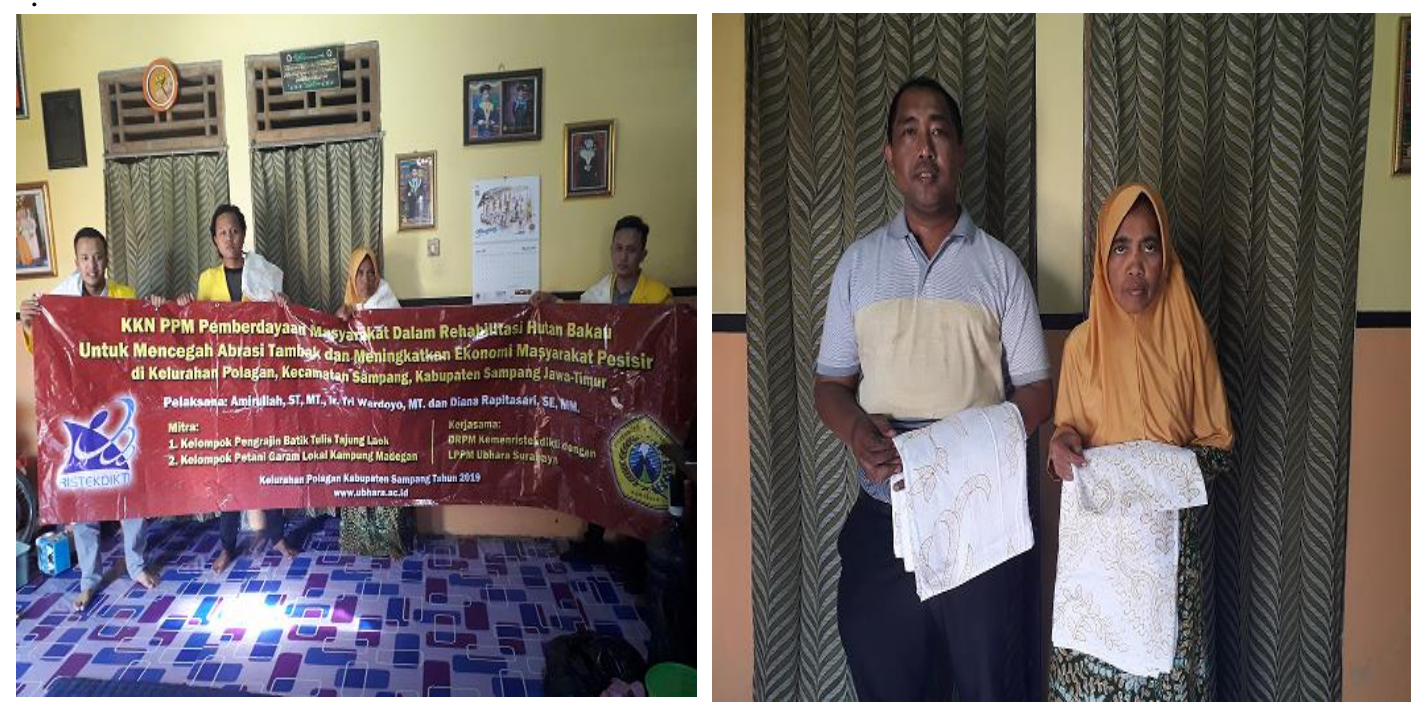

Gambar 13. Foto bersama pada acara pelatihan batik tulis pewarnaan alam di Mitra 1

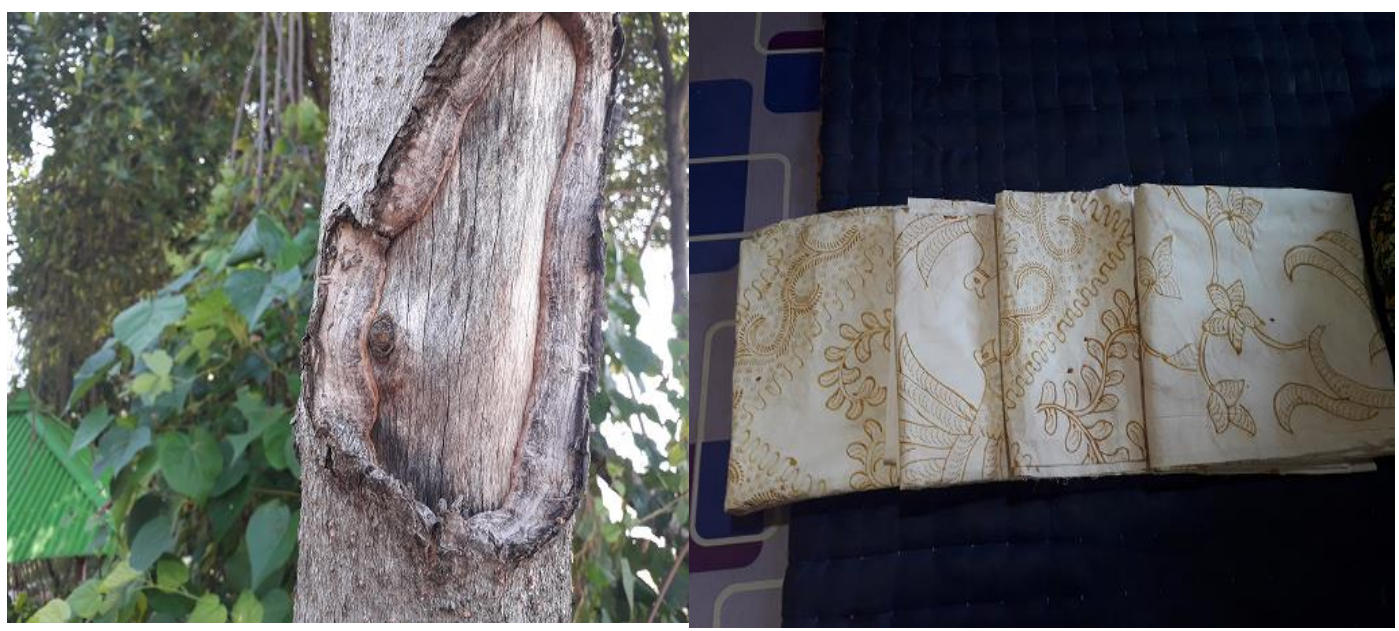

Gambar 14. Kulit pohon mangrove jenis Rhizophora Mucronata dan batik sebelum diberi pewarna alam

\section{Kesimpulan}

Pohon mangrove selain sebagai media penahan ombak alami, habitat bagi ikan maupun udang muda, dan sumber oksigen, kulit dan dahan pohonnya dapat juga dimanfaatkan sebagai salah satu bahan pewarna alam kain batik tulis. Berdasarkan latar belakang tersebut, program KKN-PPM Ubhara Surabaya 2019 melaksanakan pelatihan, sosialisasi, dan praktek pemanfaatan dahan dan kulit batang pohon mangrove sebagai bahan warna bagi pembuatan batik tulis gentongan "pewarnaan alam" kepada Kelompok Pengrajin Batik Tulis Tajung Laok.Bahan dahan dan kulit batang berasal dari pohon mangrove jenis Rhizophora Mucronata (mangrove atau tinjang).Implementasi kegiatan lapangan KKN-PPM diharapkan mampumeningkatkan kualitas batik tulis Motif Tajung. Kegiatan juga diharapkan mampu memberikan edukasi, meningkatkan pemahamandan kesadaran, serta mendorong masyarakat supaya ikut menjaga dan menjaga kelestarian pohon mangrove di pesisir pantai Kelurahan Polagan Kabupaten Sampang. 


\section{Ucapan Terima Kasih}

Program berjudul “KKN PPM Pemberdayaan Masyarakat Dalam Rehabilitasi Hutan Mangrove Untuk Mencegah Abrasi Tambak dan Meningkatkan Ekonomi Masyarakat Pesisir di Kelurahan Polagan Kecamatan Sampang Kabupaten Sampang Jawa-Timur" dibiayai Direktorat Jenderal Penguatan Riset dan Pengembangan Kementerian Riset, Teknologi, dan Pendidikan Tinggi sesuai Kontrak Abdimas LLDikti VII dan Risbang: Nomor: 111/SP2H/PPM/DRPM/2019 Tanggal 11 Maret 2019 dan Kontrak LLDikti VII dan Universitas Bhayangkara Surabaya Nomor: 007/SP2H/PPM/L7/2019 Tanggal 26 Maret 2019.

\section{Daftar Pustaka}

Anonim. (2017a). ILMU PENGETAHUAN. Retrieved October 4, 2019, from http://www.organisasi.org/

Anonim. (2017b, September 19). Motif Batik Sampang Khas Madura Provinsi Jawa Timur. Retrieved October 4, 2019, from Informasi Batik Indonesia website: https://infobatik.id/577-2/

Panggabean, (n.d.). Eksplorasi Teknik Crochet Dengan Tema Warna Empat Musim Untuk Busana Muslimah. (2013), 10.

Amirulloh, Tri Wardoyo, Pemanfataan Buah Dan Daun Bakau (Mangrove) Untuk Produk Minuman Dan Makanan Bernilai Ekonomis Tinggi, (2019).

Rapitasari, D. (n.d.). PENINGKATAN MANAJEMEN MUTU DAN PEMASARAN PRODUK UMKM JILBAB DAN BAJU MUSLIM. (2019), 12.

Syariful Alim, Agus Kiswantono, (2016), Ipteks bagi Masyarakat (IbM) Peningkatan Kualitas, Manajemen, dan Pemasaran Batik Tulis Motif Tajung Melalui Penambahan "Aromaterapi" di Kelurahan Polagan Kecamatan Sampang Kabupaten Sampang Jawa-Timur, (1),172-185,

Tri Wardoyo, Achmad Yulianto, (2016), Ipteks bagi Masyarakat (IbM) Peningkatan Kualitas, Efisiensi, dan Manajemen Batik Tulis Gentongan Tanjung Bumi "Pewarnaan Alam" di Desa Peseseh Kecamatan Tanjung Bumi Kabupaten Bangkalan Jawa-Timur, (1),121-137 
Afiliasi:

Amirullah*, Tri Wardoyo,

Teknik Elektro Fakultas Teknik, Teknik Sipil Fakultas Teknik

Universitas Bhayangkara Surabaya

Jalan Ahmad Yani 114 Surabaya 60231

E-mail: amirullah@ubhara.ac.id, triwardoyo_ubhara@yahoo.co.id,

*) Penulis Korespondensi

Diana Rapitasari

Manajemen Fakultas Ekonomi dan Bisnis

Universitas Bhayangkara Surabaya

Jalan Ahmad Yani 114 Surabaya 60231

dianarapitasari@gmail.com 